\title{
Geochemistry and Petrogenesis of Basaltic Rocks and Enclosed Xenoliths from the Ghab Pliocene Volcanic Field in Northwestern Syria
}

\author{
Ali T. Al-Mishwat1*, Safwan S. Dawod² \\ ${ }^{1}$ Department of Earth and Environmental Sciences, Kuwait University, Kuwait City, Kuwait \\ ${ }^{2}$ Department of Geology, Damascus University, Latakia, Syria \\ Email: ${ }^{\star}$ lemonfather@yahoo.com
}

How to cite this paper: Al-Mishwat, A.T. and Dawod, S.S. (2021) Geochemistry and Petrogenesis of Basaltic Rocks and Enclosed Xenoliths from the Ghab Pliocene Volcanic Field in Northwestern Syria. International Journal of Geosciences, 12, 667-688. https://doi.org/10.4236/ijg.2021.128038

Received: June 18, 2021

Accepted: August 15, 2021

Published: August 18, 2021

Copyright $\odot 2021$ by author(s) and Scientific Research Publishing Inc. This work is licensed under the Creative Commons Attribution International License (CC BY 4.0).

http://creativecommons.org/licenses/by/4.0/

(c) (i) Open Access

\begin{abstract}
Basaltic rocks and their content of ultramafic xenoliths are common in the Ghab Pliocene Volcanic Field in northwestern Syria in the form of lava flows, cinder cones and pyroclastic deposits. The rocks occur within the Ghab pullapart graben that formed by sinister strike slip faults within the zone that defines the boundary between the African and the Arabian plates. Three petrographic types occur: basanite, olivine basalt and more commonly alkali olivine basalt. The peridotite xenoliths are spinel lherzolite and harzburgite. Geochemical analysis indicates that the basalts are mostly alkaline to subalkaline. A distinctive feature of these rocks is the narrow compositional variations in the content of most major oxides and minor elements, $\mathrm{SiO}_{2}(44.33$ $46.43 \mathrm{wt} \%)$ and $\mathrm{MgO}(4.01-8.28 \mathrm{wt} \%)$. Some of the refractory and high field strength elements and incompatible minor elements in the basalts are relatively high $(\mathrm{Cr}$ average $=303 \mathrm{ppm}$ and $\mathrm{Ni}$ average $=185 \mathrm{ppm})$ compared with their content in average basalts. These geochemical characteristics reflect crystallization of the Ghab basalts from pristine and primary magmas that have experienced minimal fractional crystallization and crustal contamination. Similarly, chemical compositions of the ultramafic xenoliths vary within a restricted geochemical range. They are compatible with the generation of these rocks from partial melting of a primitive mantle pyrolite to yield the xenoliths. These magmatic processes operated during the Pliocene in a regional transtensional stress environment attending the development of the Dead Sea Rift.
\end{abstract}

\section{Keywords}

Basalt, Xenolith, Ghab, Syria, Pliocene 


\section{Introduction}

The northwestern part of the Arabian Plate, especially along the Dead Sea Fault Zone (DSFZ; Figure 1(a)), has experienced a repeated and voluminous volcanic activity during the last $20 \mathrm{Ma}$ [1] and has continued from the Miocene to the present. [2] suggested a period of volcanic quiescence between 16 and $8 \mathrm{Ma}$.

The Ghab Pliocene Volcanic Field (GPVF), which is the focus of this paper, comprises a small part of the eastern-most province of the encompassing CircumMediterranean Anorogenic Cenozoic Igneous Province (CMACI) described by [3].

[4] represented a petrographic evidence, as well as major element, trace element, and isotopic data, from the Ghab and Homs region. They suggested a possible model for the derivation of basaltic magmas attendant with the propagation of the Dead Sea Rift.

[5] considered the Cenozoic flood basalts of Syria as belonging to the Arabian-Levant large igneous province (LIP). The province provides information on the composition of the super plume material and processes in the plume head causing the volcanic activity. [6] discussed the geometry of the Turkey-Arabia fault line in the Miocene to Mid-Pliocene.

The present study attempts to establish relationships between the Ghab basalts
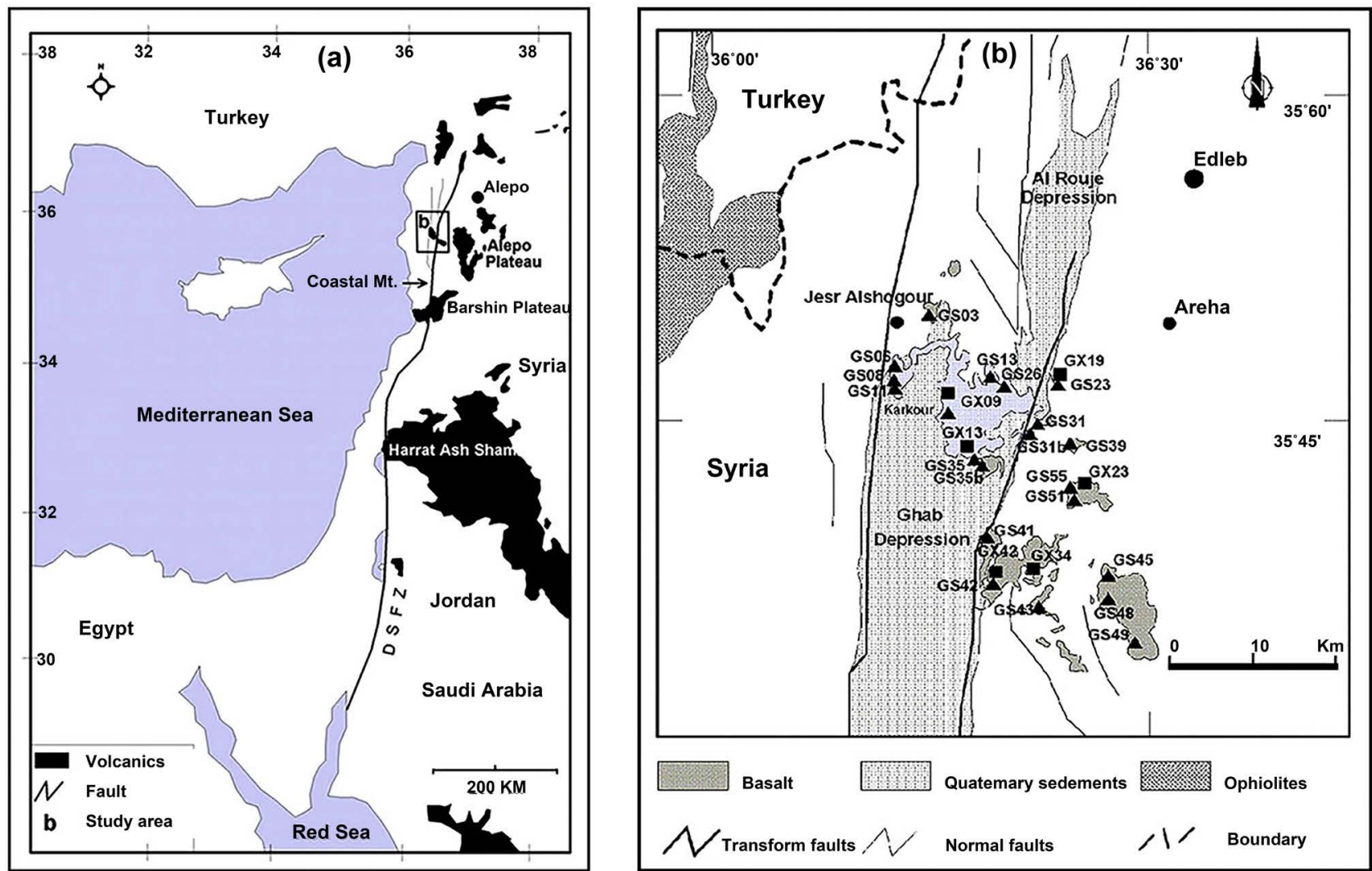

Figure 1. (a) A regional map showing the distribution of the Neogene basaltic volcanic fields in the northwestern part of the region. (b) is a simple geological map of basaltic occurrences in the Ghab region showing the locations of basaltic samples $(\boldsymbol{\Delta})$ and sites of ultramafic xenoliths (-). 
and their enclosed ultramafic xenoliths. The paper also serves to add geochemical data to the dataset on the GPVF and to enhance the geochemical archives on the Syrian volcanic rocks [7].

The study describes the basaltic rocks and ultramafic xenoliths that were erupted during the Pliocene in the Ghab region of northwestern Syria and dominated by alkali basalt, alkali olivine basalt and basanite.

Because of the association of these mafic lava fields with tectonic activities in the Pliocene, and of their content of rich assemblages of ultramafic mantle xenoliths, their investigation is likely to provide evidence of, and to shed light, on the nature of the sub-continental lithospheric mantle beneath the northwestern part of the Arabian Plate.

The present study is a part of ongoing investigations of basaltic rocks from Syria. The results of these investigations appeared in [8] [9] [10].

\section{Ghab Pliocene Volcanic Field}

The Ghab Graben developed as a pull-apart basin during the Pliocene-Quaternary time [11]. It underlies a young and mature Quaternary alluvial plain that is about $60 \mathrm{~km}$ by $10 \mathrm{~km}$, in which the GPVF occupies an area of about 60 square kilometers. The GPVF assumes a general north-south direction. Complex leftlateral fault systems (Figure 1(b)) bound the GPVF along its eastern and western margins.

The volcanism in the eastern and northern parts of the Ghab region resulted in the development of a large basaltic plateau. This volcanic mass forms a high ridge (several tens of meters) inside the plain and separates the Al Rouge depression in the north from the Ghab depression in the south (Figure 1(b)). The western part of this ridge, the Karkour Pass, developed during the Pliocene.

\section{Pliocene Volcanism}

Basalts were erupted over large areas in the northwestern part of Syria in the Arabian Plate during the Pliocene, and some flows host abundant ultramafic xenoliths. Volcanic rocks of the GPVF fall into four groups: 1) massive vesicular flows containing xenoliths, 2) alternating thin $(30-60 \mathrm{~cm}$ ) flows of basalts, 3) massive tuffaceous flows containing xenoliths, and 4) pyroclastic and fragmental successions. The massive tuffaceous layers form the upper parts of flows in the basaltic sequences and occur at the margins of volcanic centers.

Pliocene volcanic flows of the first three types of basaltic rocks are massive, tabular and dissected. The stack of basaltic rocks on the western flank of the Alwastani Mountain exemplifies these flows (Figure 2(a)), which rises to an elevation of about $800 \mathrm{~m}$ above the Ghab plain.

Xenoliths of the GPVF are common in the different volcanic rock types in the region. They occur as extensive basalt flows, as well as forming cores of volcanic bombs and other pyroclastic and tuffaceous materials. The shape of most xenoliths is irregular, being mostly elongated from $4 \mathrm{~cm}$ to $20 \mathrm{~cm}$; in rare cases, they 


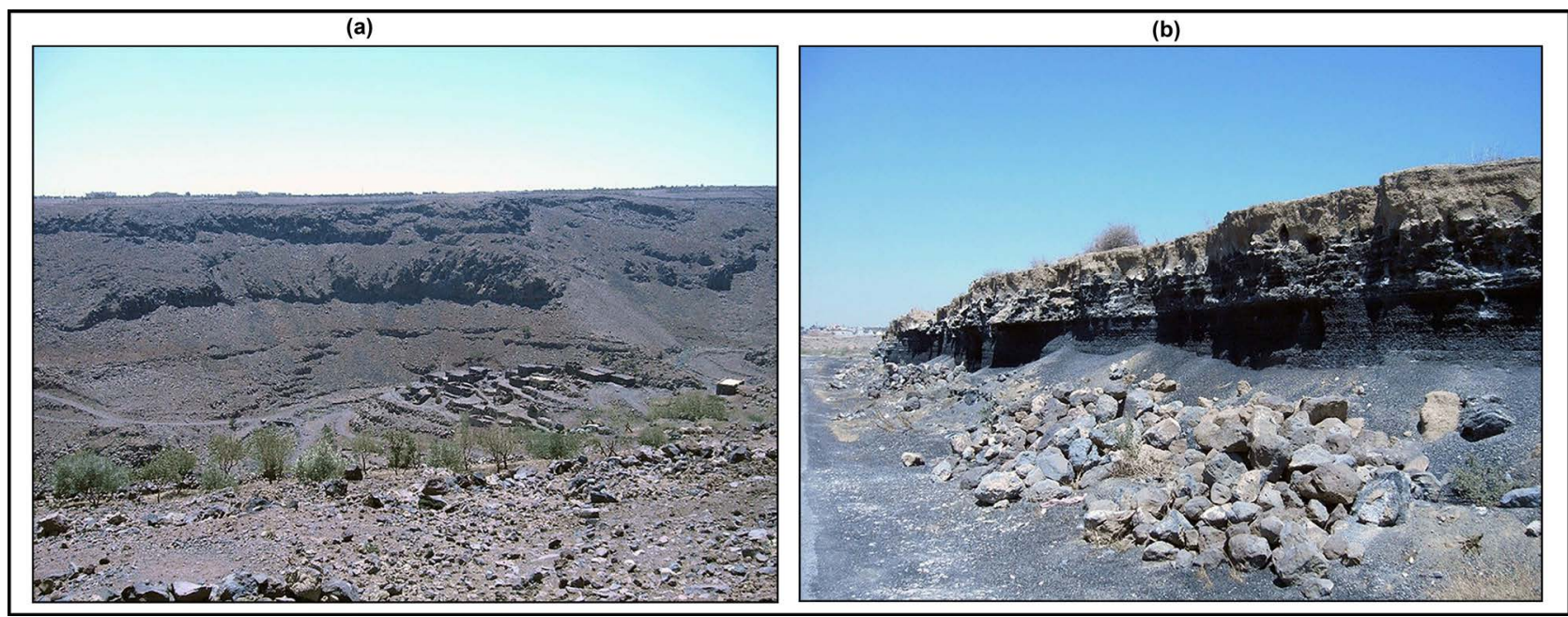

Figure 2. (a) A thick stack of alternating massive and thin flows of basaltic rocks in the Alwastani Mountain. Basanite forms most of the flows. (b) Thin flows of basaltic rocks in the Jesr Alshoguor area. Alkali olivine basalt forms most of the flows.

measure up to $25 \mathrm{~cm}$ in diameter. [12] discussed mantle xenoliths and their mineralogy and geochemistry.

\section{Analytical Methods}

Twenty fresh basaltic samples and six xenoliths were collected from the GPVF for performing the geochemical analysis. Each rock sample was crushed, ground and powdered in a tungsten carbide mill. Major elements oxides were determined on fused glass disks prepared according to the method of [13].

Trace elements were determined on pressed pellets of rock powders. Five grams of each rock sample powder was fluxed with ten grams of flux prepared by thorough mixing of Lithium tetraborate ( $80 \mathrm{wt} \%$ ) and Lithium metaborate (20 wt\%). This mixture enhances the characteristic elemental radiation count rates and the sensitivity and accuracy of the XRF elemental determinations. Pressed powder pellets were prepared by pressing in a hydraulic press under a pressure between 15 and 20 tons. The same procedures were applied to the calibration standards. Both glass disks and pressed pellets have a diameter of 34 millimeters and a thickness of $4 \mathrm{~mm}$. Loss on ignition (L.O.I) was determined on one gram of pre-dried rock powders. Subsequently, the powders were ignited at $1100^{\circ} \mathrm{C}$ for 5 hours in a high-temperature muffle furnace. Concentrations of elements were corrected for the weight loss and oxidation. One gram of the pre-dried powder was used to determine contents of $\mathrm{Fe}_{2} \mathrm{O}_{3}$ according to standard wet chemical methods. Instrumental analysis of samples was carried out on a fully computer-controlled SIEMENS SRS3000 sequential wavelength XRF spectrometer equipped with a Rhodium target tube, $3 \mathrm{KW}$ power load, and eight crystal spectrometers. A proprietary SPECTRA PLUS software was used for running the spectrometer and managing the data collection, calculation, and reduction. Sixty internationally certified natural silicate rock standards are utilized for establishing the calibration curves for elements. Analytical accuracy is within $5 \%$ for major elements and within $10 \%$ to 
$15 \%$ for minor elements.

\section{Results}

\subsection{Petrography and Classification}

\section{Ghab Pliocene Volcanic Field Basalts}

The dominant basaltic petrographic rock types in the GPVF are basanites, alkali basalts and alkali olivine basalts (Table 1). They are composed mainly of olivine, plagioclase, and augite phenocrysts set within a fine-grained to slightly mediumgrained matrix containing intergranular growth. Most samples are glomeroporphyritic with glass in the groundmass.

Plagioclase is the most abundant mineral ( $7 \%$ to $24 \%$ by volume; Table 2 ). It occurs as euhedral to subhedral grains or as small microliths within the matrix. It is mostly optically un-zoned, but some grains show rare oscillatory zoning and sericite alteration. Olivine is the second most dominant mineral phase, forming between $6 \%$ and $20 \%$ of the rock volume (Table 2). It occurs as subhedral phenocrysts, commonly surrounded by iddingsite rims. In most samples, olivine contains inclusions of idiomorphic spinel.

Clinopyroxene ( $6 \%$ to $12 \%$ by volume) forms subhedral phenocrysts showing the characteristic near-orthogonal simple and sector zoning. It occurs within the microcrystalline matrix or in association with olivine and plagioclase clusters. In some samples, the pyroxene crystals are engulfed by rims of fine-grained magnetite, which occasionally occurs as small inclusions along the margins. A brownishgreen hornblende is generally found in the sodium-rich samples and is frequently

Table 1. Average frequency distribution of the different lithotypes and basaltic rock field names in the volcanic stratigraphy of the GPVF.

\begin{tabular}{ccc}
\hline Lithotypes & Frequency (Percent) & Rock name \\
\hline Alkali basalt & 58 & Basalt \\
Alkali basalt & 7 & Trachybasalt \\
Alkali olivine basalt & 12 & Basalt \\
Alkali olivine basalt & 23 & Basanite \\
\hline
\end{tabular}

Table 2. Modal composition (volume \%) of the main minerals in the GPVF basalts.

\begin{tabular}{cccc}
\hline & Alkali basalt & Alkali olivine basalt & Basanite \\
\hline Olivine & $6-17$ & $12-18$ & $15-20$ \\
Clinopyroxene & $6-9$ & $8-12$ & $6-10$ \\
Plagioclase & $9-24$ & $8-22$ & $7-20$ \\
Anorthoclase & $3-4$ & $2-4$ & $2-3$ \\
Magnetite & $2-4$ & $2-4$ & $2-4$ \\
Ilmenite & $2-3$ & $2-4$ & $2-3$ \\
Glass & $4-8$ & $4-5$ & $3-6$ \\
\hline
\end{tabular}


inter-grown with the clinopyroxene. Accessory minerals include magnetite, ilmenite and apatite. Glass constitutes about $4 \%$ to $8 \%$ in some of the groundmass in the GPVF basaltic rocks. (Figure 3)

\subsection{Ultramafic Xenoliths}

Ultramafic xenoliths are classified in this study according to the scheme of [14]. Xenoliths associated with the Ghab basaltic magmas are mostly chromium spineperidotite type, including lherzolite and harzburgite.

It consists of three primary minerals: forsterite, enstatite and chromium diopside. Petrographically, the GPVF ultramafic xenoliths have a medium-grained equigranular texture. In these rocks, the mineral grain boundaries meet at interfacial angles of $120^{\circ}$ that sometimes encloses anhedral phlogopite along the grain boundaries. Olivine is subhedral and optically homogeneous. It is mostly fresh with minimal alteration. Pyroxene is subhedral, but some grains are anhedral and display the characteristic $\sim 90^{\circ}$ cleavage.

Some xenoliths contain dark melt pockets of different sizes, and some of the pyroxene grain are spongy with tiny droplets of glass. Spinel is present as anhedral crystals in all samples of the Ghab xenoliths. Contacts between olivine and

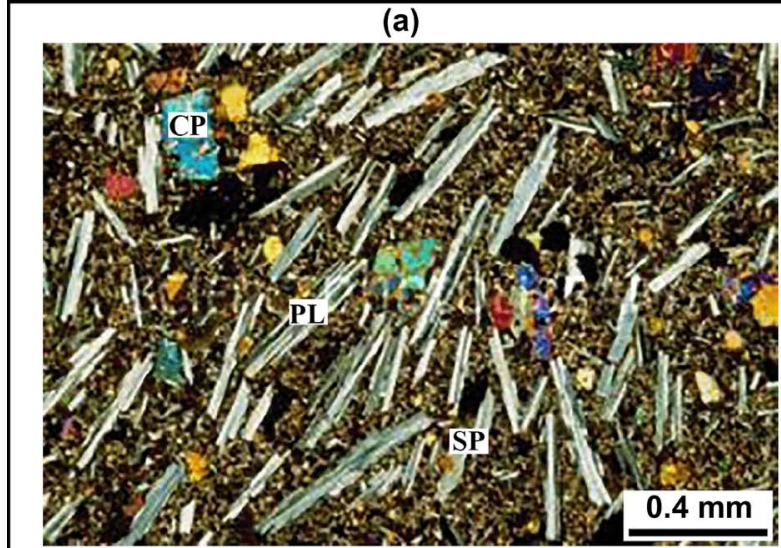

(c)

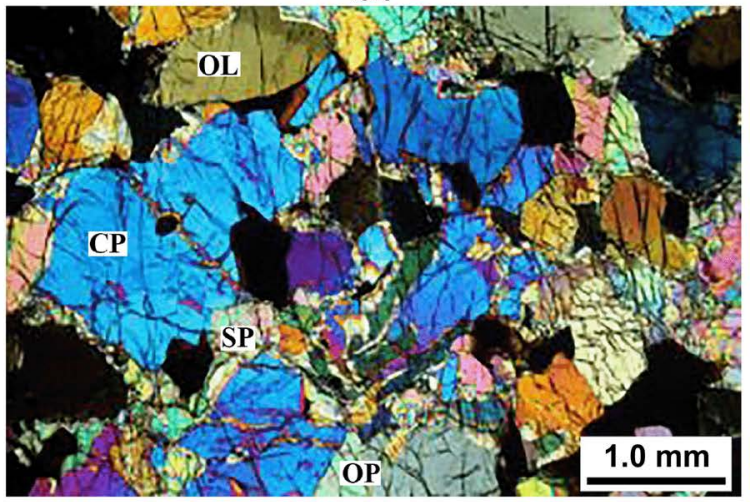

(b)

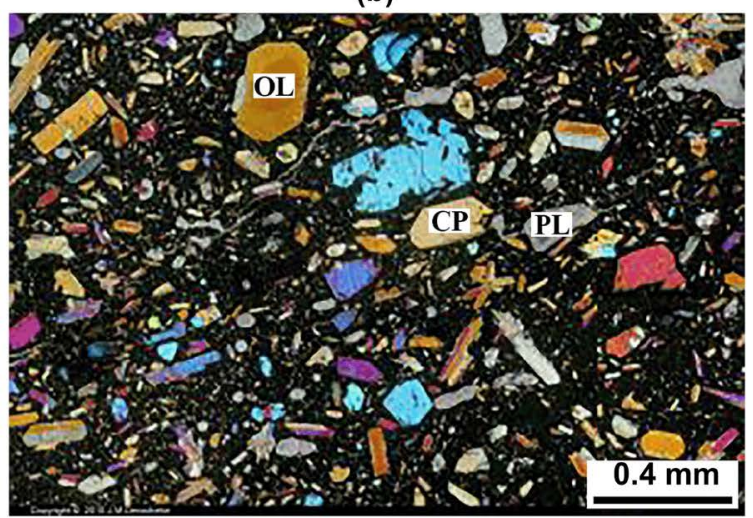

(d)

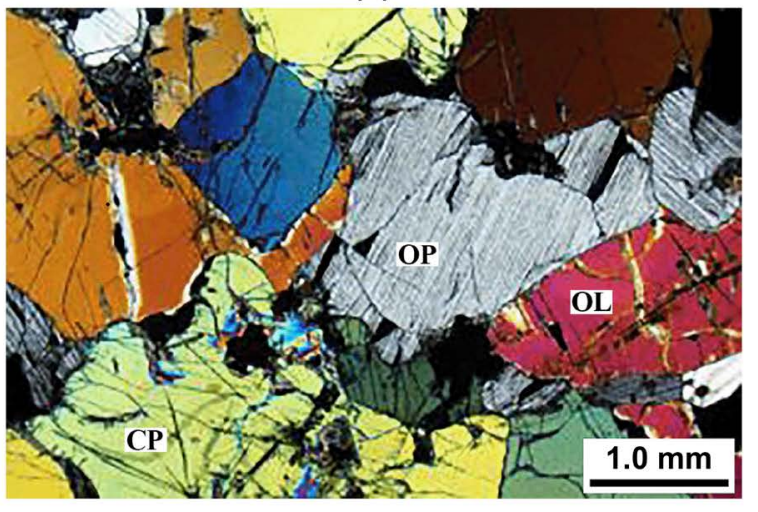

Figure 3. Photomicrographs of GPVF thin sections. (a) A basanite (Sample GS11-Table 3) from the Alwastani Mountain, (b) An alkali olivine basalt (Sample GS55-Table 3) from the Jesr Alshoguor area, (c) A lherzolite (Sample GX23Table 4) from Jesr Alshoguor area, and (d) A harzburgite (Sample GX19-Table 4) from the Jesr Alshoguor area. (CP = Clinopyroxene, $\mathrm{PL}=$ Plagioclase, $\mathrm{OL}=$ Olivine, $\mathrm{OP}=$ Orthopyroxene, $\mathrm{SP}=$ Spinel $)$. 
Table 3. (a) Content of major elements oxides (wt\%), trace elements (ppm), and CIPW norms of basalts from the GPVF. (b) Content of major elements oxides (wt\%), trace elements (ppm), and CIPW norms of basalts from the GPVF.

(a)

\begin{tabular}{|c|c|c|c|c|c|c|c|c|c|c|}
\hline Sample & GS03 & GS06 & GS08 & GS11 & GS13 & GS23 & GS26 & GS31 & GS31b & GS35 \\
\hline \multirow{2}{*}{ Lat. } & $35^{\circ} 51^{\prime}$ & $35^{\circ} 49^{\prime}$ & $35^{\circ} 49^{\prime}$ & $35^{\circ} 47^{\prime}$ & $35^{\circ} 45^{\prime}$ & $35^{\circ} 43^{\prime}$ & $35^{\circ} 44^{\prime}$ & $35^{\circ} 43^{\prime}$ & $35^{\circ} 43^{\prime}$ & $35^{\circ} 42^{\prime}$ \\
\hline & $42.79 \mathrm{~N}$ & $50.96 \mathrm{~N}$ & $42.20 \mathrm{~N}$ & $58.87 \mathrm{~N}$ & $02.31 \mathrm{~N}$ & $27.57 \mathrm{~N}$ & $05.60 \mathrm{~N}$ & $46.99 \mathrm{~N}$ & $46.95 \mathrm{~N}$ & $05.05 \mathrm{~N}$ \\
\hline \multirow{2}{*}{ Long } & $36^{\circ} 21^{\prime}$ & $36^{\circ} 20^{\prime}$ & $36^{\circ} 20^{\prime}$ & $36^{\circ} 19^{\prime}$ & $36^{\circ} 21^{\prime}$ & $36^{\circ} 21^{\prime}$ & $36^{\circ} 23^{\prime}$ & $36^{\circ} 29^{\prime}$ & $36^{\circ} 29^{\prime}$ & $36^{\circ} 29^{\prime}$ \\
\hline & $54.06 \mathrm{E}$ & $25.35 \mathrm{E}$ & $45.96 \mathrm{E}$ & $23.42 \mathrm{E}$ & $19.25 \mathrm{E}$ & $43.54 \mathrm{E}$ & $04.47 \mathrm{E}$ & $02.12 \mathrm{E}$ & $02.18 \mathrm{E}$ & $04.85 \mathrm{E}$ \\
\hline $\mathrm{SiO}_{2}$ & 46.63 & 46.24 & 44.38 & 44.33 & 44.99 & 46.34 & 45.38 & 45.74 & 45.84 & 45.23 \\
\hline $\mathrm{TiO}_{2}$ & 2.91 & 2.84 & 3.08 & 2.49 & 2.86 & 3.10 & 2.31 & 2.67 & 2.65 & 2.61 \\
\hline $\mathrm{Al}_{2} \mathrm{O}_{3}$ & 15.21 & 14.64 & 14.68 & 12.93 & 15.07 & 14.85 & 12.66 & 13.79 & 13.76 & 14.22 \\
\hline $\mathrm{Fe}_{2} \mathrm{O}_{3}$ & 7.81 & 5.34 & 8.83 & 8.47 & 7.65 & 5.39 & 9.05 & 7.36 & 7.35 & 7.30 \\
\hline $\mathrm{FeO}$ & 8.23 & 8.26 & 8.91 & 9.11 & 9.06 & 8.27 & 9.01 & 8.99 & 9.04 & 8.49 \\
\hline $\mathrm{MgO}$ & 4.01 & 6.5 & 7.28 & 8.16 & 7.38 & 7.57 & 8.02 & 6.84 & 6.79 & 7.60 \\
\hline $\mathrm{CaO}$ & 9.01 & 10.43 & 9.42 & 10.32 & 8.71 & 10.05 & 10.53 & 10.19 & 10.15 & 10.7 \\
\hline $\mathrm{Na}_{2} \mathrm{O}$ & 3.02 & 3.73 & 1.91 & 2.76 & 2.57 & 2.96 & 1.51 & 2.66 & 2.67 & 2.44 \\
\hline $\mathrm{K}_{2} \mathrm{O}$ & 1.85 & 1.91 & 1.26 & 1.01 & 1.20 & 1.35 & 0.67 & 0.93 & 0.94 & 0.85 \\
\hline $\mathrm{MnO}$ & 0.12 & 0.10 & 0.03 & 0.02 & 0.04 & 0.12 & 0.16 & 0.09 & 0.11 & 0.05 \\
\hline $\mathrm{P}_{2} \mathrm{O}_{5}$ & 0.08 & 0.11 & 0.07 & 0.12 & 0.11 & 0.08 & 0.13 & 0.10 & 0.12 & 0.07 \\
\hline L.O.I & 0.78 & 0.08 & 0.16 & 0.29 & 0.34 & 0.05 & 0.66 & 0.69 & 0.71 & 0.44 \\
\hline Total & 99.66 & 100.18 & 100.01 & 100.01 & 99.98 & 100.03 & 100.09 & 100.05 & 100.13 & 100.00 \\
\hline \multicolumn{11}{|c|}{ CIPW norms } \\
\hline DI & 17.86 & 27.46 & 15.07 & 24.97 & 13.73 & 21.06 & 21.09 & 22.15 & 22.14 & 22.14 \\
\hline HY & 4.32 & 0.00 & 13.89 & 0.00 & 6.59 & 0.00 & 15.18 & 4.93 & 5.27 & 3.49 \\
\hline OL & 0.67 & 6.52 & 0.76 & 10.05 & 7.76 & 10.33 & 0.00 & 5.39 & 5.16 & 7.25 \\
\hline AN & 22.48 & 17.56 & 27.76 & 19.91 & 26.04 & 23.51 & 25.79 & 22.94 & 22.78 & 25.34 \\
\hline OR & 10.93 & 11.29 & 7.45 & 5.97 & 7.09 & 7.98 & 3.96 & 5.50 & 5.55 & 5.02 \\
\hline MG & 11.32 & 7.74 & 12.80 & 12.28 & 11.09 & 7.81 & 13.12 & 10.67 & 10.66 & 10.58 \\
\hline IL & 5.53 & 5.39 & 5.85 & 4.73 & 5.43 & 5.89 & 4.39 & 5.07 & 5.03 & 4.96 \\
\hline $\mathrm{AP}$ & 0.19 & 0.26 & 0.17 & 0.28 & 0.26 & 0.19 & 0.30 & 0.24 & 0.28 & 0.17 \\
\hline D.I. & 36.48 & 35.19 & 23.61 & 27.63 & 28.84 & 31.21 & 19.57 & 28.00 & 28.15 & 25.67 \\
\hline $\mathrm{Mg} \#$ & 55 & 44 & 70 & 57 & 64 & 58 & 75 & 61 & 61 & 66 \\
\hline \multicolumn{11}{|c|}{ Trace elements (ppm) } \\
\hline Co & 42 & 44 & 54 & 40 & 60 & 55 & 47 & 37 & 39 & 42 \\
\hline $\mathrm{Cr}$ & 280 & 312 & 330 & 332 & 325 & 278 & 250 & 260 & 258 & 320 \\
\hline $\mathrm{Ni}$ & 113 & 145 & 162 & 209 & 155 & 146 & 145 & 150 & 153 & 160 \\
\hline $\mathrm{Ba}$ & 521 & 671 & 650 & 743 & 749 & 763 & 810 & 788 & 784 & 801 \\
\hline $\mathrm{Sr}$ & 1120 & 1302 & 1408 & 1237 & 1283 & 1136 & 1101 & 1331 & 1326 & 1278 \\
\hline $\mathrm{V}$ & 177 & 170 & 195 & 182 & 186 & 167 & 185 & 160 & 162 & 197 \\
\hline $\mathrm{Zr}$ & 225 & 210 & 187 & 232 & 226 & 239 & 247 & 215 & 211 & 258 \\
\hline $\mathrm{Nb}$ & 87 & 82 & 78 & 98 & 87 & 80 & 92 & 92 & 91 & 123 \\
\hline $\mathrm{Y}$ & 25 & 26 & 23 & 25 & 24 & 25 & 28 & 28 & 27 & 23 \\
\hline $\mathrm{Ce}$ & 129 & 142 & 136 & 123 & 149 & 141 & 135 & 131 & 127 & 127 \\
\hline
\end{tabular}


(b)

\begin{tabular}{|c|c|c|c|c|c|c|c|c|c|c|}
\hline Sample & GS35b & GS39 & GS41 & GS42 & GS43 & GS45 & GS48 & GS49 & GS51 & GS55 \\
\hline \multirow{2}{*}{ Lat. } & $35^{\circ} 42^{\prime}$ & $35^{\circ} 39^{\prime}$ & $35^{\circ} 38^{\prime}$ & $35^{\circ} 38^{\prime}$ & $35^{\circ} 38^{\prime}$ & $35^{\circ} 38^{\prime}$ & $35^{\circ} 38^{\prime}$ & $35^{\circ} 38^{\prime}$ & $35^{\circ} 37^{\prime}$ & $35^{\circ} 36^{\prime}$ \\
\hline & $22.09 \mathrm{~N}$ & $14.64 \mathrm{~N}$ & $23.70 \mathrm{~N}$ & $02.91 \mathrm{~N}$ & $18.27 \mathrm{~N}$ & $27.92 \mathrm{~N}$ & $28.45 \mathrm{~N}$ & $54.21 \mathrm{~N}$ & $05.94 \mathrm{~N}$ & $56.49 \mathrm{~N}$ \\
\hline \multirow{2}{*}{ Long. } & $36^{\circ} 29^{\prime}$ & $36^{\circ} 23^{\prime}$ & $36^{\circ} 24^{\prime}$ & $36^{\circ} 23^{\prime}$ & $36^{\circ} 24^{\prime}$ & $36^{\circ} 23^{\prime}$ & $36^{\circ} 26^{\prime}$ & $36^{\circ} 26^{\prime}$ & $36^{\circ} 26^{\prime}$ & $36^{\circ} 26^{\prime}$ \\
\hline & $04.81 \mathrm{E}$ & $29.09 \mathrm{E}$ & $56.05 \mathrm{E}$ & $37.64 \mathrm{E}$ & $08.27 \mathrm{E}$ & $38.81 \mathrm{E}$ & $40.76 \mathrm{E}$ & $22.38 \mathrm{E}$ & $11.65 \mathrm{E}$ & $39.74 \mathrm{E}$ \\
\hline $\mathrm{SiO}_{2}$ & 45.34 & 45.11 & 45.35 & 45.67 & 45.96 & 45.35 & 44.86 & 44.79 & 46.27 & 44.38 \\
\hline $\mathrm{TiO}_{2}$ & 2.58 & 2.91 & 2.84 & 2.87 & 3.06 & 3.10 & 0.98 & 3.07 & 2.55 & 2.76 \\
\hline $\mathrm{Al}_{2} \mathrm{O}_{3}$ & 14.17 & 14.94 & 14.53 & 15.03 & 14.77 & 14.69 & 12.48 & 14.74 & 13.27 & 14.81 \\
\hline $\mathrm{Fe}_{2} \mathrm{O}_{3}$ & 7.84 & 9.97 & 9.45 & 8.02 & 8.98 & 9.05 & 10.64 & 7.98 & 8.58 & 6.83 \\
\hline $\mathrm{FeO}$ & 8.44 & 8.25 & 7.97 & 8.36 & 7.59 & 7.70 & 9.30 & 8.09 & 8.26 & 8.91 \\
\hline $\mathrm{MgO}$ & 7.62 & 6.82 & 7.41 & 6.55 & 6.46 & 6.26 & 7.57 & 7.13 & 6.50 & 8.28 \\
\hline $\mathrm{CaO}$ & 10.56 & 8.88 & 9.10 & 9.68 & 8.92 & 9.74 & 9.75 & 9.83 & 10.63 & 9.42 \\
\hline $\mathrm{Na}_{2} \mathrm{O}$ & 2.45 & 1.54 & 1.64 & 1.87 & 2.72 & 2.59 & 1.89 & 2.58 & 2.58 & 2.39 \\
\hline $\mathrm{K}_{2} \mathrm{O}$ & 0.91 & 1.41 & 1.60 & 1.81 & 1.20 & 1.22 & 1.02 & 0.91 & 0.94 & 1.61 \\
\hline $\mathrm{MnO}$ & 0.05 & 0.15 & 0.20 & 0.17 & 0.14 & 0.09 & 0.08 & 0.11 & 0.16 & 0.13 \\
\hline $\mathrm{P}_{2} \mathrm{O}_{5}$ & 0.09 & 0.11 & 0.09 & 0.08 & 0.07 & 0.08 & 0.12 & 0.08 & 0.10 & 0.08 \\
\hline L.O.I & 0.04 & 0.13 & 0.01 & 0.05 & 0.23 & 0.21 & 1.38 & 0.72 & 0.22 & 0.39 \\
\hline Total & 100.22 & 100.19 & 100.16 & 100.10 & 100.08 & 100.07 & 100.03 & 100.06 & 99.98 & 100.09 \\
\hline \multicolumn{11}{|c|}{ CIPW norms } \\
\hline DI & 21.83 & 11.32 & 13.85 & 16.52 & 15.48 & 18.45 & 20.71 & 17.98 & 17.03 & 17.43 \\
\hline HY & 4.12 & 13.76 & 14.08 & 12.44 & 10.75 & 7.72 & 15.58 & 5.86 & 11.96 & 0.00 \\
\hline OL & 6.60 & 0.00 & 0.00 & 0.00 & 0.00 & 0.54 & 0.00 & 0.00 & 0.00 & 13.23 \\
\hline AN & 24.98 & 29.69 & 27.56 & 27.27 & 24.55 & 24.85 & 22.56 & 25.95 & 31.34 & 24.93 \\
\hline OR & 5.38 & 8.33 & 9.45 & 10.70 & 7.09 & 7.21 & 6.03 & 5.38 & 1.30 & 9.51 \\
\hline MG & 11.37 & 14.45 & 13.70 & 11.63 & 13.02 & 13.12 & 15.43 & 14.47 & 12.44 & 9.90 \\
\hline IL & 4.90 & 5.53 & 5.39 & 5.45 & 5.81 & 5.89 & 1.86 & 5.83 & 4.84 & 5.24 \\
\hline AP & 0.21 & 0.26 & 0.21 & 0.19 & 0.17 & 0.19 & 0.28 & 0.19 & 0.24 & 0.19 \\
\hline D.I. & 26.11 & 25.07 & 25.30 & 26.54 & 30.23 & 29.12 & 22.34 & 29.02 & 19.61 & 28.65 \\
\hline $\mathrm{Mg} \#$ & 65 & 73 & 70 & 67 & 61 & 63 & 67 & 65 & 87 & 62 \\
\hline
\end{tabular}

Trace elements (ppm)

\begin{tabular}{ccccccccccc} 
Co & 45 & 42 & 56 & 42 & 43 & 56 & 46 & 48 & 51 & 56 \\
$\mathrm{Cr}$ & 324 & 327 & 331 & 316 & 289 & 328 & 271 & 270 & 247 & 330 \\
$\mathrm{Ni}$ & 158 & 188 & 164 & 146 & 115 & 157 & 150 & 160 & 158 & 193 \\
$\mathrm{Ba}$ & 796 & 746 & 652 & 668 & 583 & 745 & 695 & 732 & 771 & 805 \\
$\mathrm{Sr}$ & 1271 & 1233 & 1403 & 1305 & 1123 & 1280 & 1311 & 1351 & 1320 & 1405 \\
$\mathrm{~V}$ & 195 & 183 & 193 & 171 & 176 & 184 & 193 & 180 & 186 & 190 \\
$\mathrm{Zr}$ & 255 & 232 & 185 & 213 & 224 & 227 & 219 & 261 & 256 & 241 \\
$\mathrm{Nb}$ & 124 & 99 & 79 & 81 & 85 & 88 & 78 & 109 & 98 & 119 \\
$\mathrm{Y}$ & 24 & 26 & 26 & 24 & 26 & 24 & 26 & 28 & 22 & 23 \\
$\mathrm{Ce}$ & 129 & 124 & 144 & 135 & 126 & 147 & 135 & 144 & 136 & 140 \\
\hline
\end{tabular}


Table 4. Content of major elements oxides (wt\%) and trace elements (ppm) of xenoliths from the GPVF.

\begin{tabular}{ccccccc}
\hline Sample & GX09 & GX13 & GX19 & GX23 & GX34 & GX42 \\
\hline Xenolith & lherzolite & harzburgite & Harzburgite & lherzolite & harzburgite & lherzolite \\
\hline $\mathrm{SiO}_{2}$ & 43.08 & 43.06 & 42.05 & 43.75 & 43.38 & 43.88 \\
$\mathrm{TiO}_{2}$ & 0.12 & 0.07 & 0.06 & 0.24 & 0.11 & 0.02 \\
$\mathrm{Al}_{2} \mathrm{O}_{3}$ & 2.14 & 1.53 & 1.06 & 3.52 & 2.98 & 1.97 \\
$\mathrm{Cr}_{2} \mathrm{O}_{3}$ & 0.29 & 0.15 & 0.55 & 0.34 & 0.30 & 0.38 \\
$\mathrm{Fe}_{2} \mathrm{O}_{3}$ & 9.66 & 9.48 & 9.31 & 9.34 & 8.64 & 8.38 \\
$\mathrm{MgO} \mathrm{O}$ & 41.26 & 44.19 & 45.97 & 39.01 & 42.32 & 42.68 \\
$\mathrm{CaO}$ & 2.72 & 0.87 & 0.57 & 3.10 & 1.86 & 1.55 \\
$\mathrm{Na}_{2} \mathrm{O}$ & 0.42 & 0.07 & 0.06 & 0.36 & 0.07 & 0.13 \\
$\mathrm{~K}_{2} \mathrm{O}$ & 0.07 & 0.02 & 0.01 & 0.01 & bd & 0.02 \\
$\mathrm{MnO}$ & 0.14 & 0.11 & 0.13 & 0.12 & 0.12 & 0.08 \\
$\mathrm{P}_{2} \mathrm{O}_{5}$ & 0.01 & 0.03 & bd & 0.02 & 0.01 & bd \\
$\mathrm{L} . \mathrm{O} . \mathrm{I}$ & 0.13 & 0.40 & 0.18 & 0.12 & 0.15 & 0.20 \\
$\mathrm{Total}$ & 100.04 & 99.98 & 99.95 & 99.93 & 99.94 & 99.29 \\
$\# \mathrm{Mg}$ & 90.29 & 90.91 & 89.63 & 90.05 & 90.14 & 89.98 \\
\hline & & & & & & \\
\hline
\end{tabular}

pyroxene occasionally show reaction corona textures in which amphibole replaces pyroxene, and spinel and magnetite replace olivine. Some of the xenolith samples show signs of variable metasomatism, like thin veins of fine-grained phlogopite.

\section{Geochemistry}

Results of the major element oxides and minor element analysis of the GPVF basalts and xenoliths are listed in Table 3(a), Table 3(b), and Table 4. The inhouse CIPWFULL FORTRAN software program [15] was used to calculate the normative composition of the GPVF basalts. The CIPW norms of the Ghab basalts are listed in Table 3(a) and Table 3(b). The computer code for the CIPWFULL software program is available from the link in the CIPWFULL reference [15].

\subsection{Ghab Pliocene Volcanic Field Basalts}

Chemical compositions of the GPVF basalts show high alkalinity values for $\mathrm{Na}_{2} \mathrm{O}$ $+\mathrm{K}_{2} \mathrm{O}$, permitting them to be classified as mainly alkali basalt and basanite on the basis of the TAS classification scheme of [16] (Figure 4).

Figure 5(a) shows the major elements chemistry. $\mathrm{SiO}_{2}$ contents vary in a narrow range between $44.33 \mathrm{wt} \%$ and $46.63 \mathrm{wt} \%$. MgO shows variations from 4.01 wt $\%$ to $8.28 \mathrm{wt} \%$. The $\mathrm{K}_{2} \mathrm{O}$ content varies from $0.67 \mathrm{wt} \%$ to $1.91 \mathrm{wt} \%$, while the $\mathrm{Na}_{2} \mathrm{O}$ content changes from $1.5 \mathrm{wt} \%$ to $3.73 \mathrm{wt} \%$. The $\mathrm{Al}_{2} \mathrm{O}_{3}$ content of the Ghab 


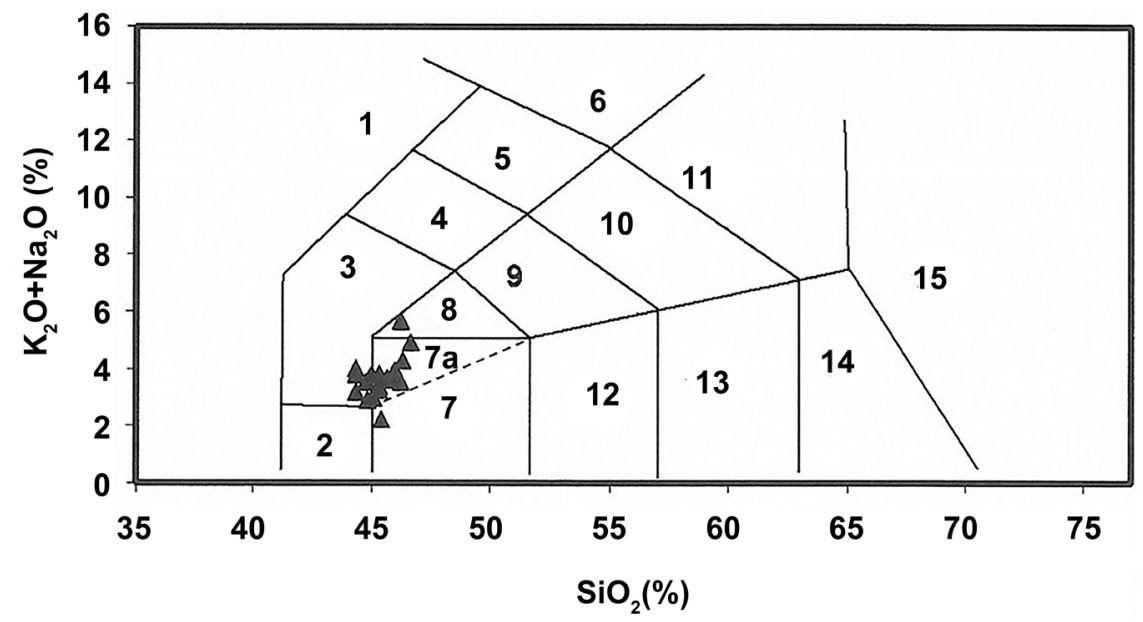

1-Foidite 2-Picro-basalt 3-Basanite 4-Phono-tephrite 5-Tephri-phonolite 6-Phonolite

7-Basalt 8-Trachy-basalt 9-Basaltic trachy-andesite 10-Trachy-andesite 11-Trachyte

12-Basaltic andesite 13-Andesite 14-Dacite 15-Rhyolite (7a-Alkali basalt)

Figure 4. A total alkalis-silica (TAS) diagram [16] showing the chemical classification of the GPVF basalt samples. (Symbols as in Figure 1(b)).

(a)
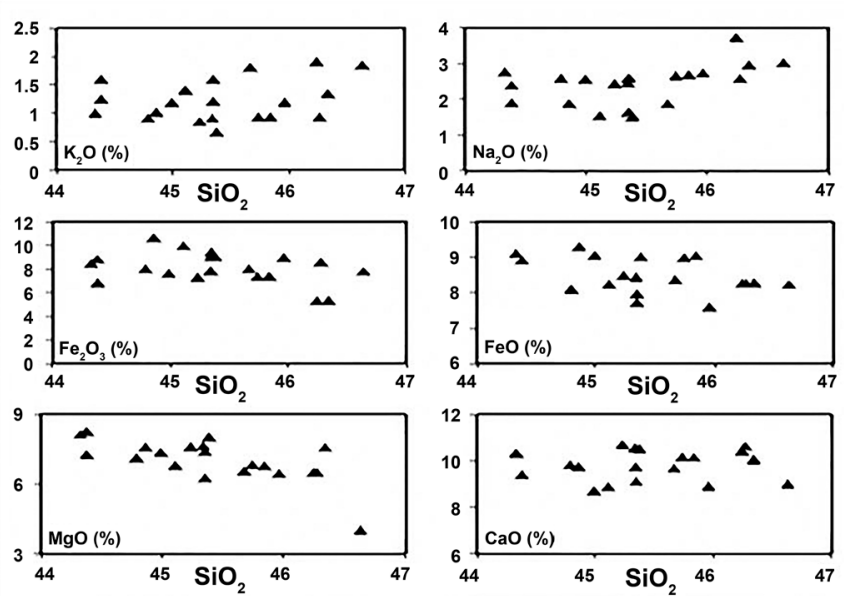

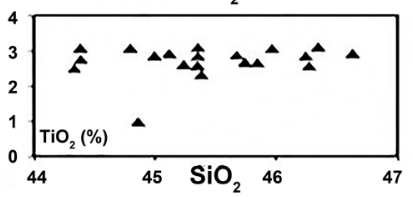

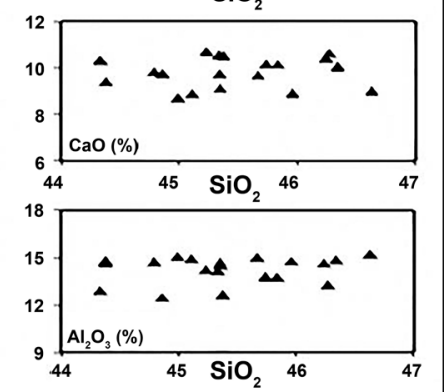

(b)
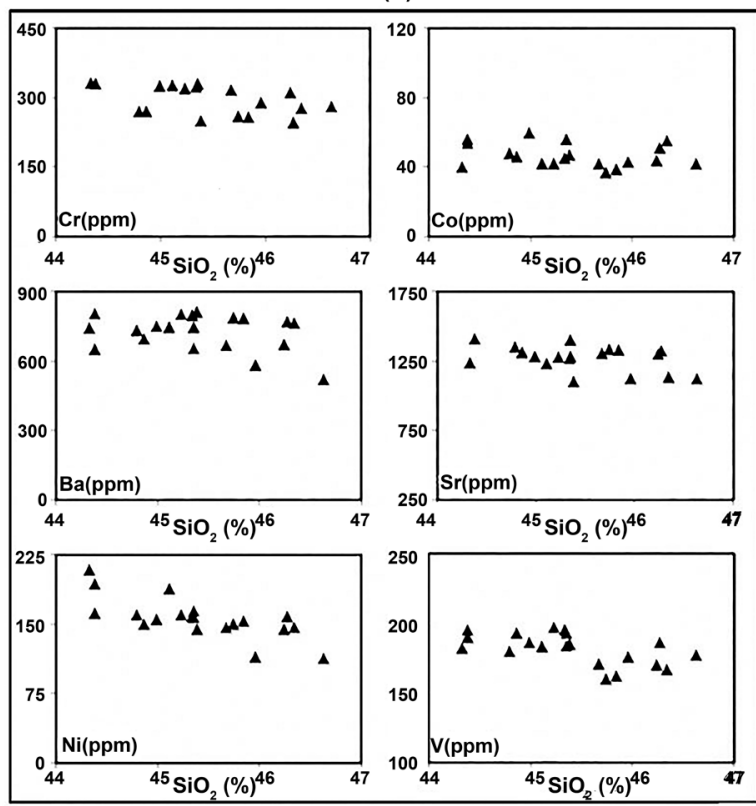

Figure 5. Harker variations diagrams for the basaltic rocks of the GPVF. The figure shows (a) major elements oxides (wt\%) variations vs. silica, and (b) minor elements variations (ppm) vs. silica. (Symbols as in Figure 1(b))

volcanic samples varies from $12.48 \mathrm{wt} \%$ to $15.21 \mathrm{wt} \%$, averaging $14.25 \mathrm{wt} \%$. The $\mathrm{FeO}$ content is mostly uniform in these basalts and the total iron is generally similar in most samples. It ranges from $13.6 \mathrm{wt} \%$ to $18.07 \mathrm{wt} \%$. The $\mathrm{TiO}_{2}$ content varies between $0.98 \mathrm{wt} \%$ and $3.1 \mathrm{wt} \%$. The differentiation index (D.I.) calculated for the GPVF basalts spans a range of $18 \%$ to $35 \%$, with an average value of about $28 \%$. 
As shown by Figure 5(b) the rocks are characterized by high concentration of Co (42 to $56 \mathrm{ppm}$ ), Ni (113 to $193 \mathrm{ppm}$ ), Cr (247 to $331 \mathrm{ppm}$ ), and V (160 to 197 $\mathrm{ppm})$. The average $\mathrm{Ni}$ content of $185 \mathrm{ppm}$ is higher than the value of $145 \mathrm{ppm}$ reported for $\mathrm{Ni}$ in alkali basalt by [17].

Strontium and barium contents vary from 1123 to $1405 \mathrm{ppm}$ and from 583 to 805 ppm, respectively, with Sr averaging $1300 \mathrm{ppm}$ and Ba averaging $719 \mathrm{ppm}$. These averages are higher than the values of $1069 \mathrm{ppm}$ and $546 \mathrm{ppm}$ reported for these two elements by [18] for basaltic rocks from northern Syria. The Zr content in the investigated samples ranges from 185 to $261 \mathrm{ppm}$, whereas the $\mathrm{Nb}$ content ranges from 78 to $124 \mathrm{ppm}$. The $\mathrm{Y}$ content varies in a narrow range between 20 and $30 \mathrm{ppm}$.

\subsection{Ghab Pliocene Volcanic Field Ultramafic Xenoliths}

The two most abundant oxides in the ultramafic xenoliths of the GPVF, $\mathrm{SiO}_{2}$ and $\mathrm{MgO}$, vary in extremely narrow compositional ranges. They change from $42.73 \mathrm{wt} \%$ to $43.67 \mathrm{wt} \%$ in the case of $\mathrm{SiO}_{2}$ and from $41.34 \mathrm{wt} \%$ to $43.81 \mathrm{wt} \%$ in the case of the $\mathrm{MgO}$, for spinel lherzolite and spinel harzburgite. In addition, the xenoliths show variations in the $\mathrm{Al}_{2} \mathrm{O}_{3}$ and $\mathrm{CaO}$ contents, and exhibit higher contents of both elements in the spinel lherzolite (Figure 6).

Figure 6 shows chemical variations of the major elements $\left(\mathrm{Al}_{2} \mathrm{O}_{3}, \mathrm{CaO}\right.$ and $\mathrm{TiO}_{2}$ ), and the minor element $\mathrm{Cr}_{2} \mathrm{O}_{3}$ versus $\mathrm{MgO}$ (wt\%) for the GPVF ultramafic xenoliths. The plots for the first three elements are compared with variations of these elements in ultramafic xenoliths elsewhere [19] [20] [21].

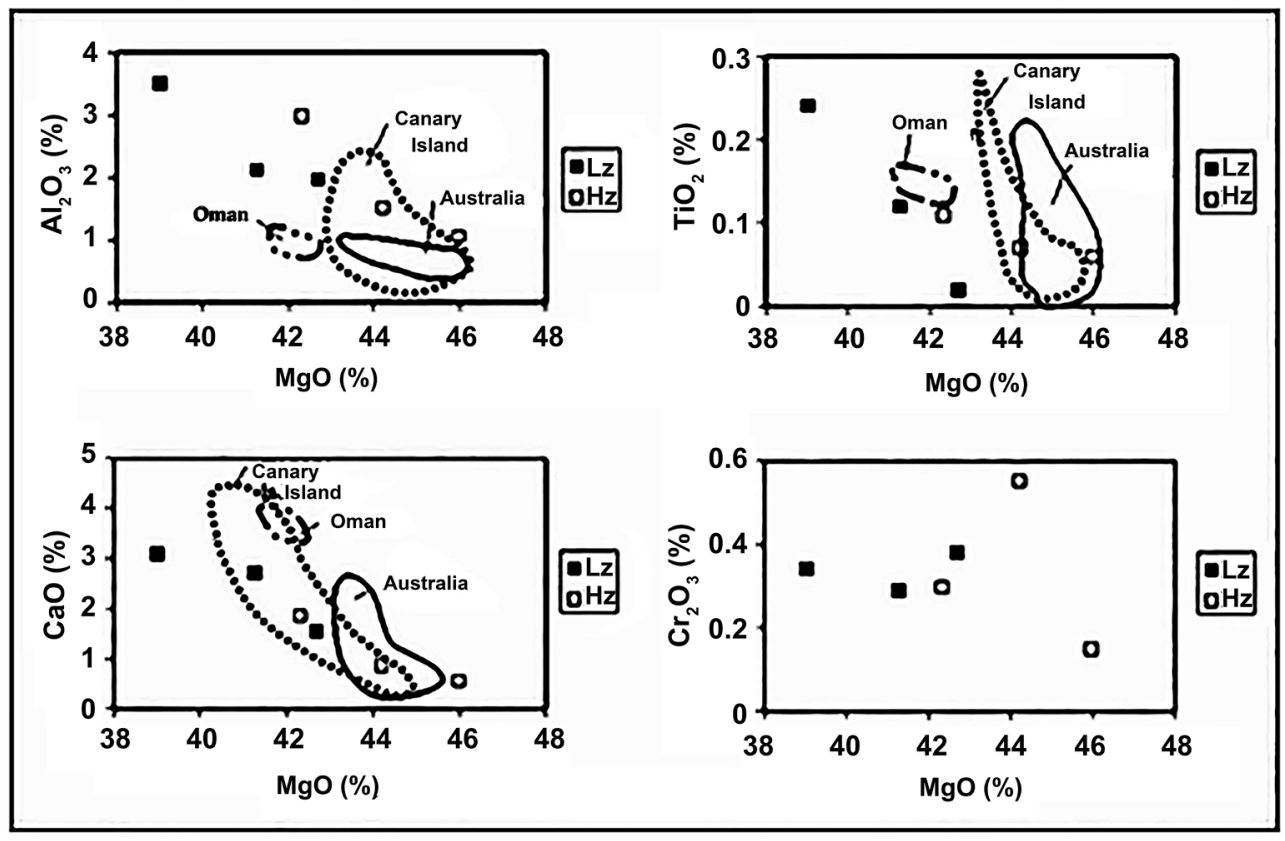

Figure 6. Chemical variations of the major elements $\mathrm{Al}_{2} \mathrm{O}_{3}, \mathrm{CaO}$ and $\mathrm{TiO}_{2}$, and the minor element $\mathrm{Cr}_{2} \mathrm{O}_{3}$ versus $\mathrm{MgO}$ (wt\%) for the GPVF ultramafic xenoliths. The plots for the first three elements are compared with variations of these elements in ultramafic xenoliths elsewhere ([19] [20] [21]). (Lz = Lherzolite, $\mathrm{Hz}=$ Harzburgite). (Symbols as in Figure 1(b)) 
Bulk compositions of these spinel peridotite xenoliths in the Ghab region display a low content in $\mathrm{Al}_{2} \mathrm{O}_{3}, \mathrm{CaO}$ and $\mathrm{TiO}_{2}$ when plotted against $\mathrm{MgO}$ (Figure 6).

\section{Discussion}

\subsection{Ghab Pliocene Volcanic Field Basalts}

Generally, the differentiation index for the GPVF rocks is relatively low, indicating possibly a limited differentiation in the magma chamber supplying magmas to the surface of the Ghab region. The relatively high normative olivine reflects the high content of magnesium and iron oxides in the rocks. The magnesium number $(\mathrm{Mg} \#)$ is exceptionally high and is almost unity $(89.63-90.91)$.

Overall variations in the content of major element oxides and minor elements in the GPVF basaltic rocks show limited concentration ranges. Such uniformity in the chemical composition reflects possibly the operation of several competing petrological processes during the genesis of these rocks, although this interpretation is derived only from a small investigation field area.

These petrological processes involve partial melting of the mantle source, crystallization of basaltic liquids during their ascent to the surface, and crystallization at shallow depths and on the surface.

\subsection{Homogeneity of the Ghab Pliocene Magmas}

Several geochemical features of the GPVF basalts show that the compositional variations cover only restricted concentration ranges.

The most critical feature suggesting homogeneity of the magmas is the relatively small ranges of the differentiations index (D.I.) (averaging 27.6) and the Mg\# which ranges from 44 to 87 and averages around 64 (Table 3(a) and Table 3(b)).

For some elements in the GPVF basalts like $\mathrm{SiO}_{2}, \mathrm{TiO}_{2}, \mathrm{Sr}, \mathrm{V}$, and $\mathrm{Co}$, the variations display minimal changes (Figure 5(a) and Figure 5(b)). In some instances, the contents of these elements remain nearly constant.

The diagram for $\mathrm{Y}-\mathrm{Nb}$ variations (Figure 7) does not display a clear correlation

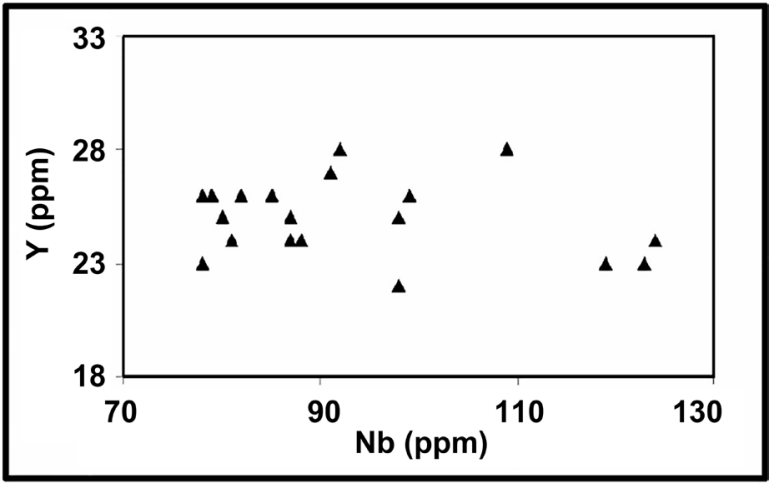

Figure 7. A Y versus $\mathrm{Nb}$ diagram for the GPVF basaltic rocks (Symbols as in Figure $1(\mathrm{~b}))$. 
between these two elements, due to the near constant $Y$ values of 22 to $28 \mathrm{ppm}$. This behavior contrasts with diagrams showing positive correlations. The behavior of these two elements in the GPVF rocks is attributed to the strong chemical homogeneity displayed by the magmas crystallizing these rocs.

The plots showing the relationships between $\mathrm{Ni}$ and $\mathrm{MgO}$ and $\mathrm{Co}$ and $\mathrm{MgO}$ (Figure 8(a)) display a similar behavior as that of the major chemistry (Figure 5(a)), and thus supports a similar reasoning. These two plots show the Ghab basalts as clusters lacking evidence for systematic variations. This situation is different from the $\mathrm{Ni}$ and $\mathrm{Co}$ cases showing clear crystal fractionation and positive relationships (e.g. [23]), and attests to the homogeneity of the investigated Ghab rocks. This strong uniformity in the major element composition thus indicate a coherent chemical character for the magmas of the GPVF, leading to the conclusion of minimal modifications of their composition from the time of generation by partial melting until extrusion.

\section{Limited Fractionation and Differentiation}

Fractionation and differentiation have played a very limited role in the evolution

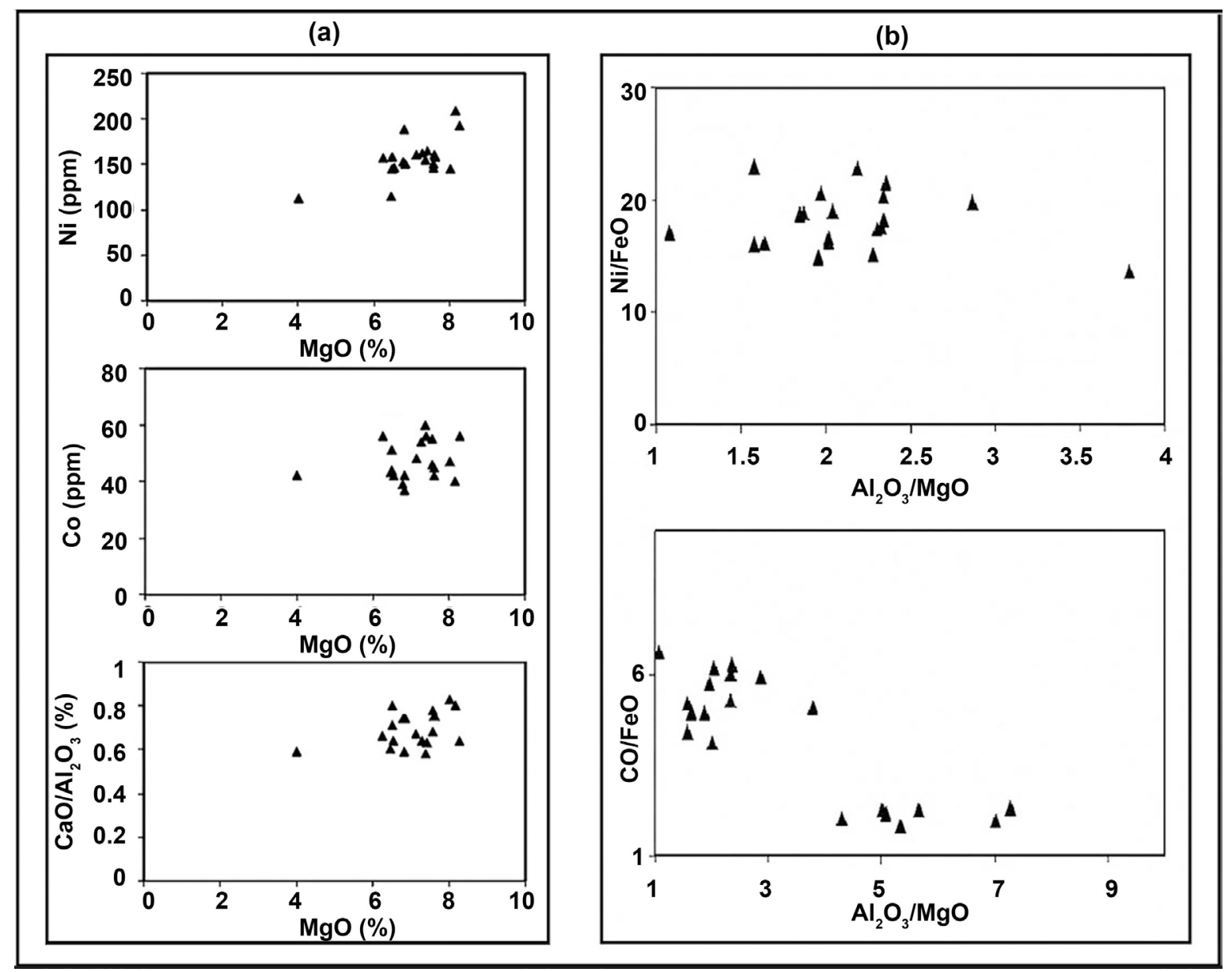

Figure 8. (a) The content of the $\mathrm{Ni}$ and $\mathrm{Co}$, and the $\mathrm{CaO} / \mathrm{Al}_{2} \mathrm{O}_{3}$ ratio plotted against $\mathrm{MgO}$ for the GPVF basaltic rocks. (b) The relationships between the $\mathrm{Ni} / \mathrm{FeO}$ and the $\mathrm{Co} / \mathrm{FeO}$ ratios plotted against the $\mathrm{Al}_{2} \mathrm{O}_{3} / \mathrm{MgO}$ ratio for the GPVF basaltic rocks. Plot after [22]. (Symbols as in Figure 1(b)) 
of the GPVF basaltic magmas. The relatively narrow range of $\mathrm{MgO}$, in addition to the clustering in the three plots in Figure $8(\mathrm{a})\left(\mathrm{Ni}\right.$, Co and $\mathrm{CaO} / \mathrm{Al}_{2} \mathrm{O}_{3}$ vs. $\mathrm{MgO}$ ), is evidence for an insignificant or lack of fractionation and differentiation [24]. This is attributed to a rapid rise of the magmas through the upper mantle and the crust, precluding the possibility of differentiation. This, in turn, suggests the magmas did not reside intermittently along its path through the continental lithosphere, circumventing the possibility for mineral separation and fractionation. Furthermore, this reasoning, along with the magma homogeneity suggested above, implies the GPVF magmas are close to their initial pristine composition at the site of the partial melting, and the lack of any subsequent significant differentiation and fractionation.

The geochemical behavior of $\mathrm{Cr}$ in the GPVF volcanic rocks (Figure 5(b)) supports the contention expressed above for the negligible role of fractionation. Chromite and chrome-spinel, the main repository of $\mathrm{Cr}$ in basaltic rocks, crystallize at an early stage of solidification of primary magmas. High concentration of $\mathrm{Cr}$ in the earliest crystallization product from primary mafic magmas is explained adequately by fractionation of chromite, reinforced by an early coupled separation of chrome-spinel (or $\mathrm{Cr}$ in solid solution in magnetite) and clinopyroxene, as suggested by [25]. Such a scenario is applicable to the situation in the GPVF basalts, where both of these phases form constituents in the analyzed samples.

The slight negative correlation between $\mathrm{Cr}$ and silica in the GPVF (Figure $5(b))$ is attributed to the fractionation of clinopyroxene and minor quantities of Cr-spinel from the initial magma, an interpretation similar to that of [26]. Yet, another observed feature of $\mathrm{Cr}$ in the Ghab basalts is the relatively high content of $\mathrm{Cr}(299 \mathrm{ppm})$ that is much higher than twice the value of $142 \mathrm{ppm}$ tabulated by [27] for primary basaltic magmas. This relatively high $\mathrm{Cr}$ content in the basalts is inconsistent with the Ghab magmas having undergone any significant differentiation or crystal accumulation.

In view of the similarity in chemical affinity between $\mathrm{Ni}$ and $\mathrm{Cr}$, a similar reasoning is advanced as an explanation for the pattern of Ni variations in the Ghab volcanic rocks, but the controlling crystallizing phase for $\mathrm{Ni}$ is fundamentally olivine. The decrease in the Ni content with silica in the Ghab rocks (Figure 5(b)) may be ascribed to a fractionation mechanism solely involving the extraction of olivine [26]. Thus, relatively high abundances of $\mathrm{Cr}$ and $\mathrm{Ni}$ in the GPVF basalts testify to a very small change in the magma composition since its inception. [28] reached a similar explanation for the Harrat Al Fahda basaltic rocks in Jordan.

Another illustration pertaining to this lack of differentiation-fractionation is the relationship between each of the ratios of $\mathrm{Ni} / \mathrm{FeO}$ and $\mathrm{Co} / \mathrm{FeO}$ and the $\mathrm{Al}_{2} \mathrm{O}_{3} / \mathrm{MgO}$ ratio (Figure $8(\mathrm{~b})$ ). The plot of $\mathrm{Ni} / \mathrm{FeO}$ in the figure shows this ratio in the lavas to vary between 17 and 23 , while the $\mathrm{Co} / \mathrm{FeO}$ ratio ranges from 2 to 6. [22] Used similar plots to assess the degree of fractionation and concluded 
that only clearly unambiguous relationships in them can be utilized as evidence for fractionation. An application of this logic to the Ghab volcanic rocks shows that changes in these ratios display a lack of relationship in the first plot in (Figure $8(\mathrm{~b}))$ and a negative relationship in the second plot in. The covariation in the $\mathrm{Ni}$ case displays a very insignificant relationship, while the covariation in the Co case shows a negative trend (Figure 8(b)). The Co plot displays a clear and slightly steeper slope than in the Ni plot.

The Pearson correlation coefficient ( $\mathrm{r}$ ) was calculated for the Ni and Co magnitude of linearity. The $(r)$ values were $(-0.43)$ for the Ni case and $(0.01)$ for the Co case. These values are very low and support the conclusion for lack of differentiation. Even when the outlier sample (GS03) was excluded from the regression, the resultant $(\mathrm{r})$ values were $(-0.09)$ for $\mathrm{Ni}$ and $(0.25)$ for Co. The overall explanation for the low and nearly flat covariations is the absence of any sign of differentiation and fractionation in the Ghab Pliocene volcanic rocks and their parent magmas.

$\mathrm{Ba}$ and $\mathrm{Sr}$ readily substitute for $\mathrm{K}$ in K-feldspar (anorthoclase in the GPV basalts) and Ca-plagioclase, respectively. Variations in the content of these two elements in the GPVF basalts thereby reflect the fractionation of these two phases. The constant level of content of both elements argues against much fractionation of these minerals. Nonetheless, the slight decrease of $\mathrm{Ba}$ at the highest level of silica values in these rocks may reflect a selective, but limited and late, fractionation of anorthoclase.

The most likely cause for the magnitude of the differentiation index (D.I.) and the magnesium number $(\mathrm{Mg \# )}$, as well as the invariability in the content of most major and minor elements, is an attainment of a long-lived, continuous melt extraction and homogenization, stipulated at the site of the partial melting supplying magmas to the surface of the Ghab region. This is augmented by a very limited fractionation and differentiation during the magma ascent to the surface

\subsection{Magma Mixing and Crustal Contamination}

The extent of magma mixing has a direct influence on chemical variations of magmas. It requires the coexistence of magmas with contrasting chemical compositions.

When relevant, magma-mixing processes are represented by mixing lines in plots like that relating $\mathrm{Zr}$ and $\mathrm{Nb}$ abundances in the $\mathrm{Zr}-\mathrm{Nb}$ variation space. These two elements generally produce a linear trend of variation, similar to that in Figure 9(a). This plot of the $\mathrm{Zr}-\mathrm{Nb}$ co-variations for the GPVF rocks illustrates that their concomitant co-variation falls far from the mixing line (dashed line). This divergence signifies the improbability of magma mixing as a viable mechanism during the genesis of the GPVF basalts.

In addition, the noticeable lack of crustal felsic xenoliths in the GPVF xenolith assemblage that was entrained by the Ghab Pliocene basaltic magmas argues against a substantial involvement of crustal lithologies and contamination of the 

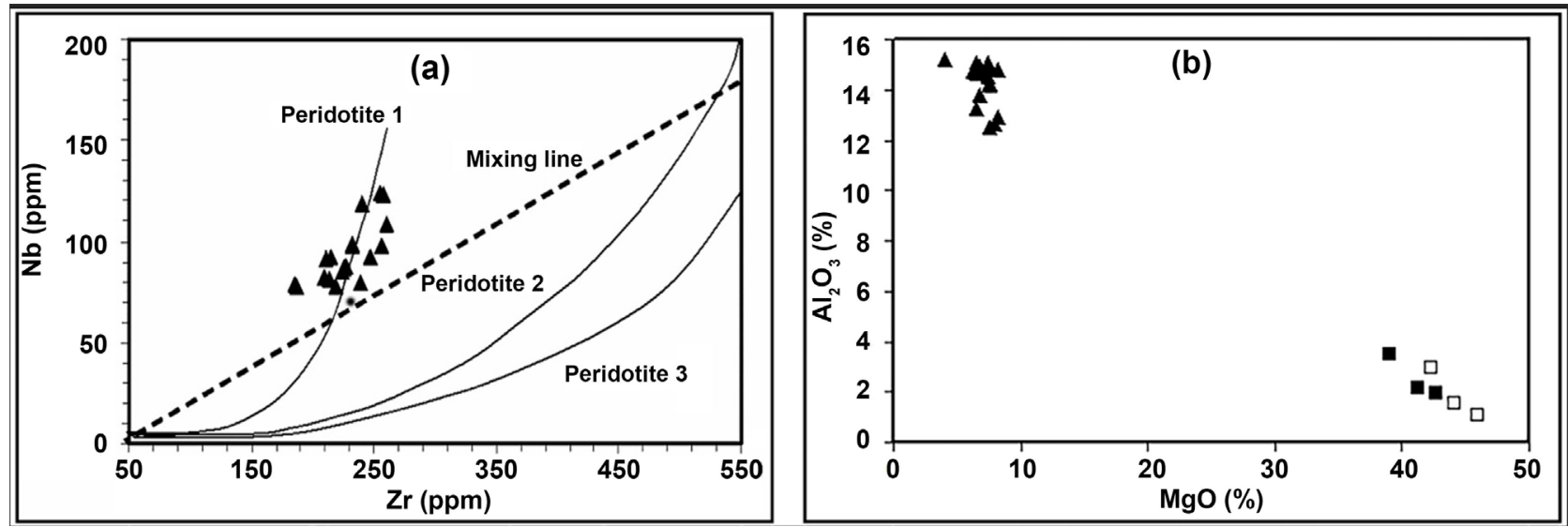

Figure 9. (a) A Nb - Zr plot for the modeling of partial melting of peridotites [29] and the line of mixing (after [30] [31]). The three curves peridotite-1, peridotite- 2 and peridotite- 3 correspond each to a model peridotite composition with the following olivine-orthopyroxene-clinopyroxene-garnet ratios: (0.50: 0.25:0.20:0.05), (0.58:0.27:0.13:0.02), (0.65:0.28:0.05:0.02). The dashed line of mixing is discussed in the text, and (b) is a plot of the variations of $\mathrm{Al}_{2} \mathrm{O}_{3}$ vs. $\mathrm{MgO}$ (Plot after [32]) showing the changes in $\mathrm{MgO}$ $\mathrm{Al}_{2} \mathrm{O}_{3}$ relationship in the Ghab ultramafic xenoliths, according to a spinel-bearing lherzolite line, for the GPVF ultramafic xenoliths. (Symbols as in Figure 1(b)).

magmas. This interpretation is similar to that reached by ([18] [33]), who stipulated for basalts from other areas in Syria only a limited upper crustal contribution from an ancient Proterozoic basement.

\subsection{Partial Melting}

The three curves in Figure 9(a) peridotite-1, peridotite-2 and peridotite-3 correspond each to a model $\mathrm{d}$ peridotite composition with the following olivine-orthopyroxene-clinopyroxene-garnet ratios: (0.50:0.25:0.20:0.05), (0.58:0.27:0.13:0.02) and (0.65:0.28:0.05:0.02).

The partial melting process responsible for the generation of basaltic melts is analyzed with the aid of this $\mathrm{Zr}-\mathrm{Nb}$ plot [29]. The plot shows a summary of partial melting of three different pyrolite models, each containing peridotite assemblages with contrasting contents of olivine, clinopyroxene, orthopyroxene and garnet [29]. The $\mathrm{Zr}$ - Nb plot shows the three-pyrolite models capable of production of basaltic liquids. Each of these models shows as a unique and discrete curve that predicts the behavior of these two elements during melting.

Figure 9(a) illustrates the application of this plot to the GPVF case. The Z $\mathrm{Nb}$ variations adhere very closely, and are in a good agreement, with the curve displaying partial melting of model peridotite 1. Most likely, this interpretation points to a mantle source region whose composition approximates a peridotite of mineral constitution similar to this peridotite model in the plot.

\subsection{Ghab Pliocene Volcanic Field Ultramafic Xenoliths}

Ultramafic xenoliths generally constitute a common component in basaltic rocks, and their origins link them to the upper mantle. They are also associated with mafic alkaline rocks. Compared with other Cenozoic peridotite xenoliths trapped in basalts in settings belonging to oceanic extensional environments (Oman) ([19] 
[20] [21]), the Ghab xenoliths record chemical variations which resemble more variations in xenoliths from continental extensional rifting settings than those from other environments.

The GPVF xenoliths display generally negative correlations between the contents of $\mathrm{Al}_{2} \mathrm{O}_{3}, \mathrm{CaO}$, and $\mathrm{TiO}_{2}$, and the $\mathrm{MgO}$ content (Figure 6). The variations are against $8 \%$ spread in the $\mathrm{MgO}$ content. This geochemical spread in the $\mathrm{MgO}$ values is wider than reported in xenoliths from the three regions.

Figure 6 also shows the relationship between $\mathrm{Cr}_{2} \mathrm{O}_{3}$ and $\mathrm{MgO}$ in the Ghab xenoliths. The absence of a clear relationship between the two elements is ascribed to the refractory geochemical behavior of $\mathrm{Cr}$ in $\mathrm{Cr}$-diopside and $\mathrm{Cr}$-spinel in the mantle undergoing partial melting. [34] Consider chromite as a congruently melting mineral during partial melting of peridotite in the upper mantle. The degree of this partial melting is probably small and at high pressure, as suggested by the high iron content (13.60 - 19.94 wt\%) of the GPVF basalts. This iron content is high when compared with its content from other parts of the region, like the northwestern part of the Harrat Ash Sham volcanic field [35].

The xenoliths from the GPVF are invariably separated from their host basalts by thin basalt films (less than $1 \mathrm{~mm}$ wide). This feature characterizes many of the xenoliths; it is true for xenoliths contained in the lava flows, as well as those xenoliths enclosed in the pyroclastic bombs. [35] Interpreted this texture to suggest that the basaltic magmas quenched against the xenoliths, because of the rapid transit and fast cooling of the magmas during their ascent. This minimizes the possibility of modification and alteration of the xenoliths. The spongy texture of the clinopyroxene in the xenoliths suggests the melting of this mineral during decompression while ascending through the transpression forces of the Dead Sea graben [36].

An exceptionally large abundance of xenoliths in volcanic fields indicates a mechanism of transport to the surface that involves fast transit through the lithosphere [29]. Consequently, such xenoliths are subjected to insignificant corrosion and contamination. This mode of transport is a reasonable mechanism contributing to the preservation and abundance of ultramafic xenoliths in the GPVF.

Analogous to their host basaltic lavas described earlier, the peridotite xenoliths of the GPVF display a limited variation in their chemistry (Table 4). For example, the Mg\# is almost constant (89.63 - 90.91). This very narrow compositional range can potentially lead to some ideas regarding the genesis of the xenoliths. The meager number of xenolith samples analyzed does not, however, hamper the arrival at basic conclusions in this regards.

\subsection{Relationship between Basalts and Xenoliths}

Figure 9(b) shows the $\mathrm{MgO}-\mathrm{Al}_{2} \mathrm{O}_{3}$ plot for basaltic and ultramafic xenoliths [37]. It is a plot of the relationship between $\mathrm{Al}_{2} \mathrm{O}_{3}$ and $\mathrm{MgO}$ for both the GPVF basalts and their enclosed xenoliths. Visual inspection of the trend vector shows 
that the projection of the linear variations in the xenolith compositions passes through the cluster of compositions of the basaltic samples. Such a linear array joining the two compositional end-members implies that a genetic relationship exists between the GPVF basalts and their companion xenoliths. The significance of the linearity in the xenolith $\mathrm{Al}_{2} \mathrm{O}_{3}-\mathrm{MgO}$ compositional covariation, nonetheless, is reduced by the limited spread due to the small number of xenoliths (6 samples).

The simplest interpretation in the GPVF case is the derivation of these basaltic melts from the parent lithology of the enclosed xenoliths at the site of partial melting in the mantle in the Pliocene. [37] Have used this $\mathrm{Al}_{2} \mathrm{O}_{3}-\mathrm{MgO}$ relationship to enforce the interpretation above.

[32] Presented a plot of ultramafic xenoliths collected from many regions, which shows a negative correlation between the $\mathrm{Mg} / \mathrm{Si}$ and $\mathrm{Al} / \mathrm{Si}$ ratios for the xenoliths in the plot of Figure 10(a). A line through the data points depicts the trend of crystal fractionation in such rocks [32]. This crystal fractionation trend provides a relationship that sheds light on the evolution of ultramafic xenoliths.

Figure 10(a) is such a diagram containing a plot for the GPVF xenoliths. They display a negative trend of $\mathrm{Mg} / \mathrm{Si}$ ratio against $\mathrm{Al} / \mathrm{Si}$ ratio that resembles the plot produced by [32]. This trend is viewed as indicating partial melting of a primitive

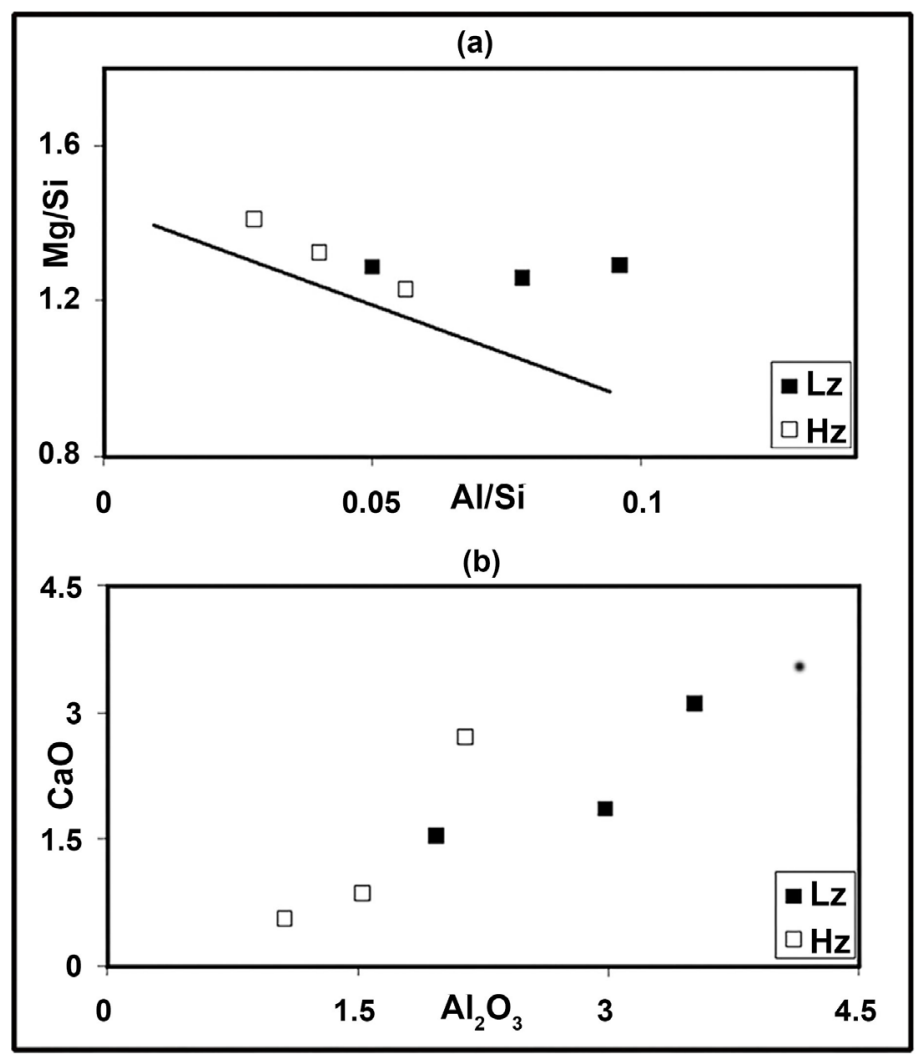

Figure 10. (a) A plot of $\mathrm{Mg} / \mathrm{Si}$ versus $\mathrm{Al} / \mathrm{Si}$ variations [32] showing the trend of $\mathrm{Mg}-\mathrm{Al}$ changes in the Ghab ultramafic xenoliths, according to a spinel-bearing lherzolite trend line, and (b) a $\mathrm{CaO}$ versus $\mathrm{Al}_{2} \mathrm{O}_{3}$ variations diagram for the GPVF ultramafic xenoliths. (Symbols as in Figure 1(b)) 
mantle source to produce lherzolite. [38] Arrived at a similar conclusion for ultramafic xenoliths from the Golan Heights in southwestern Syria. This resultant lherzolite upper mantle eventually underwent partial melting beneath the Ghab region and generated the Ghab basaltic magmas during the Pliocene.

Additionally, the GPVF xenoliths record a positive correlation between $\mathrm{Al}_{2} \mathrm{O}_{3}$ and $\mathrm{CaO}$ (Figure $10(\mathrm{~b})$ ), which, similar to the $\mathrm{Mg} / \mathrm{Si}-\mathrm{Al} / \mathrm{Si}$ plot, depicts the continuous evolution from the harzburgite field to the lherzolite field, a feature that was explained by [37] to reflect the evolution stipulated above.

\section{Conclusions}

The GPVF, the focus of this study, is a small $\left(\sim 60 \mathrm{~km}^{2}\right)$ volcanic plateau in the Ghab region in northwestern Syria. The goal of this research paper is to address the geochemistry and petrogenesis of basaltic rocks and their content of enclosed xenoliths from the GPVF. The GPVF is localized within the DSFZ that marks the tectonic plate boundary between the African and the Arabian plates. The rocks are confined to the Ghab pull-apart graben formed within this zone of sinistral motion. The GPVF basaltic rocks occur in different forms: continuous lava flows, cinder cones, and tuffaceous sheet deposits. All are associated with faults and fractures. Three petro-types of basalts occur in the field: basanite, olivine basalt and alkali olivine basalt, with the latter forming the most common variety. The xenolith assemblage includes lherzolite and harzburgite and lacks crustal xenoliths.

A distinctive feature of both the basalts and the ultramafic xenoliths is their relatively homogenous chemical composition. Most likely, this indicates that the melts were not significantly modified by differentiation, crystal fractionation, crustal contamination or magma mixing. The high content of some elements like $\mathrm{FeO}$, $\mathrm{Cr}$ and $\mathrm{Ni}$, attests to the pristine and primitive nature of these basalts. Relevant bivariate plots such as the $\mathrm{Al}_{2} \mathrm{O}_{3}-\mathrm{MgO}$ and $\mathrm{Nb}-\mathrm{Zr}$ plots suggest that the Ghab basaltic melts were generated by partial melting of a peridotite upper mantle. The homogenous chemical composition of the GPVF basalts is explained by the magmas having escaped any significant fractionation and differentiation, and indicates that the GPVF magmas are pristine, retaining their initial primitive composition. An original primitive mantle is envisaged to have fused to form the xenoliths.

The subcontinental lithosphere in which these magmatic processes operated was being deformed by transtensional stresses. The upper mantle of this lithosphere was the site of the solid-liquid magmatic mechanisms that produced the basaltic rocks and their enclosed ultramafic xenoliths in the Pliocene.

\section{Acknowledgements}

We appreciate logistical field support by Abdullkarem Abdallah from Teshreen University in Syria. We thank Michele Lustrino, Abdel-Fattah Abdel-Rahman and Rao Divi for reviewing an early version of the manuscript; their comments improved it. I thank Ahmad Abdi Hersi for assistance with the images. 
The authors are grateful to the staff of the General Institute of Geological and Mineral Resources in Syria for its support of this research. They also thank the General Research Facilities (GRF) in the College of Science in Kuwait University for providing the geochemical analyses of the studied samples through the Project SG-03/01.

\section{Conflicts of Interest}

This research poses no conflict of interest.

\section{References}

[1] Giannérini, G., Campredon, R., Feraud, G. and Abo Zakhem, B. (1988) Déformations intraplaques et volcanisme associé: exemple de la plaque arabique au Cénozoïque. Bulletin de la Société Géologique de France, 6, 937-947. https://doi.org/10.2113/gssgfbull.IV.6.937

[2] Shaw, J.E., Baker, J.A., Menzies, M.A., Thirlwall, M.F. and Ibrahim, K.M. (2003) Petrogenesis of the Largest Intraplate Volcanic Field on the Arabian Plate (Jordan): A Mixed Lithosphere-Asthenosphere Source Activated by Lithospheric Extension. Journal of Petrology, 44, 1657-1679. https://doi.org/10.1093/petrology/egg052

[3] Lustrino, M. and Wilson M. (2007) The Circum-Mediterranean Anorogenic Cenozoic Igneous Province. Earth-Science Reviews, 81, 1-65. https://doi.org/10.1016/j.earscirev.2006.09.002

[4] Ma, G., Malpas, J., Xenophontos, C. and Chan, Q. (2011) Petrogenesis of Latest Miocene Quaternary Continental Intraplate Volcanism along the Northern Dead Sea Fault System (Al Ghab-Homs Volcanic Field), Western Syria: Evidence for Lithosphere-Asthenosphere Interaction. Journal of Petrology, 52, 401-430.

https://doi.org/10.1093/petrology/egq085

[5] Sharkov, E., Bogina, M. and Chistyakov, A. (2017) Magmatic Systems of Large Continental Igneous Provinces. Geoscience Frontiers, 8, 621-640. https://doi.org/10.1016/j.gsf.2016.03.006

[6] Westaway, R., Demir, T. and Seyrek, A. (2008) Geometry of the Turkey-Arabia and Miocene to Mid-Pliocene: The Role of the Malatya-Ovacik Fault Zone in Eastern Turkey. eEarth, 3, 27-35. https://doi.org/10.5194/ee-3-27-2008

[7] Shaw, J., Baker, A., Kent, K., Ibrahim, M. and Menzies, M. (2007) The Geochemistry of the Arabian Lithospheric Mantle-A Source for Intraplate Volcanism. Journal of Petrology, 48, 1495-1512. https://doi.org/10.1093/petrology/egm027

[8] Dawod, S., Al-Mishwat, A. and Bilal, A. (2010) Alkaline Magmatic Rocks from the Late Triassic to Early Cretaceous Qastal Almaaf Melange, Northwestern Syria. Kuwait Journal of Science and Engineering, 37, 135-157.

[9] Dawod, S. and Al-Mishwat, A. (2016) The Geochemistry of Pliocene Volcanism in the Shahba Region, South of Syria. An-Najah University Journal of Research (Natural Sciences), 30, 54-70.

[10] Dawod, S., Al-Mishwat, A. and Al-Abdalla, A. (2017) Pliocene Volcanic Activity of the Harrat-Ash-Sham, South of Syria: Geochemistry and Petrogenesis. Iranian Journal of Earth Sciences, 9, 31-38.

[11] Brew, G., Lupa, J., Barazangi, M., Sawaf, T., Al-Imam, A., et al. (2001) Structure and Tectonic Development of the Ghab Basin and the Dead Sea Fault System, Syria. Journal of the Geological Society of London, 158, 665-674.

https://doi.org/10.1144/jgs.158.4.665 
[12] Nixon, P.H. (1987) Mantle Xenoliths. John Wiley, New York.

[13] Eastell, J. and Willis, J.P. (1990) A Low Dilution Fusion Technique for the Analysis of Geological Samples. X-Ray Spectrometry, 19, 3-14.

https://doi.org/10.1002/xrs.1300190103

[14] Lloyd, F.E., Nixon, P.H., Hornung, G. and Condliffe, E. (1987) Regional K-Metasomatism in the Mantle beneath the West Branch of the East African Rift: Alkali Clinopyroxenite Xenoliths in Highly Potassic Magmas. In: Nixon, P.H., Ed., Mantle Xenoliths, Wiley, Chichester, 641-659.

[15] Al-Mishwat, A. (2015) CIPWFULL: A Software Program for Calculations of Comprehensive CIPW Norms of Igneous Rocks. Mathematical Geosciences, 47, 441-453. https://doi.org/10.1007/s11004-014-9568-4

[16] Le Bas, M.J., Le Maitre R.W. and Streckeisen, A.A. (1986) A Classification of Volcanic Rocks Based on the Total Alkalis-Silica Diagram. Journal of Petrology, 27, 745-750. https://doi.org/10.1093/petrology/27.3.745

[17] Wedepohl, K.H. (1975) Contribution to Chemical Data to Assumption about the Origin of Magmas from the Mantle. Forschr Mineral Stuttgart, 52, 141-172.

[18] Lustrino, M. and Sharkov, E.V. (2006) Neogene Volcanic Activity of Western Syria and Its Relationship with Arabian Plate Kinematics. Journal of Geodynamics, 42, 115 139. https://doi.org/10.1016/j.jog.2006.06.003

[19] Nasir, S., Al-Sayigh, A., Alharthy, M. and Al-Lazki, A. (2006) Geochemistry and Petrology of Tertiary Volcanic Rocks and Related Ultramafic Xenoliths from the Central and Eastern Oman Mountains. Lithos, 1, 249-270.

https://doi.org/10.1016/j.lithos.2006.03.002

[20] Yaxley, G.M., Green, D.H. and Kamenetsky, V. (1998) Carbonatite Metasomatism in the Southeastern Australian Lithosphere. Journal of Petrology, 39, 1917-1930. https://doi.org/10.1093/petroj/39.11-12.1917

[21] Neumann, E.R., Wulff-Pedersen, E., Pearson, N.J. and Spencer, E.A. (2002) Mantle Xenoliths from Tenerife (Canary Islands): Evidence for Reactions between Mantle Peridotites and Silicic Carbonatite Melts Inducing Ca Metasomatism. Journal of Petrology, 43, 825-857. https://doi.org/10.1093/petrology/43.5.825

[22] Francalanci, L., Innocenti, F., Manetti, P. and Savascein, M.Y. (2000) Neogene Alkaline Volcanism of the Afyon-Isparta Area, Turkey: Petrogenesis and Geodynamic Implications. Mineralogy and Petrology, 70, 285-312. https://doi.org/10.1007/s007100070007

[23] Paul, D.K., Ray, A., Das, B., Patil, S.K. and Biswas, K.S. (2007) Petrology, Geochemistry and Paleomagnetism of the Earliest Magmatic Rocks of Deccan Volcanic Province, Kutch, Northwest India. Lithos, 96, 42-61.

[24] Krienitz, M., Haase, K., Mezger, K. and Shaikh-Mashail, M.A. (2007) Magma Genesis and Mantle Dynamics at the Harrat Ash Shamah Volcanic Field (Southern Syria). Journal of Petrology, 48, 1513-1542. https://doi.org/10.1093/petrology/egm028

[25] Bell, B.R., Claydon, R.V. and Rogers, G. (1994) The Petrology and Geochemistry of Cone-Sheets from the Cuillin Igneous Complex, Isle of Skye: Evidence for Combined Assimilation and Fractional Crystallization during Lithospheric Extension. Journal of Petrology, 35, 1055-1094. https://doi.org/10.1093/petrology/35.4.1055

[26] Preston, R., Bell, J.B. and Rogers, G. (1988) The Loch Scridain Xenolithic Sill Complex, Isle of Mull, Scotland: Fractional Crystallization, Assimilation, Magma-Mixing and Crustal Anatexis in Subvolcanic Conduits. Journal of Petrology, 39, 519-550. https://doi.org/10.1093/petroj/39.3.519 
[27] Hughes, C. (1982) Igneous Petrology. Development in Petrology. Elsevier, New York.

[28] Ibrahim, K.M. and Al-Malabeh A. (2006) Geochemistry and Volcanic Features of Harrat El Fahda: A Young Volcanic Field in Northwest Arabia, Jordan. Journal of Asian Earth Sciences, 27, 147-154. https://doi.org/10.1016/j.jseaes.2005.01.009

[29] Reiners, P.W. (2002) Temporal-Compositional Trends in Intraplate Basalt Eruptions: Implications for Mantle Heterogeneity and Melting Processes. Geochemistry, Geophysics, Geosystems, 3, 1525-2027. https://doi.org/10.1029/2001GC000250

[30] Sigmarsson, O., Carn, S. and Carracedo, J.C. (1988) Systematics of U-Series Nuclides in Primitive Lavas from the 1730-1736 Eruptions on Lanzarote, Canary Islands, and Implications for the Role of Garnet Pyroxenites during Oceanic Basalt Formations. Earth and Planetary Science Letters, 162, 137-151. https://doi.org/10.1016/S0012-821X(98)00162-9

[31] Thomas, L.E., Hawkesworth, C.J., Van Calsteren, P., Turner, S.P. and Rogers, N.W. (1999) Melt Generation beneath Ocean Islands: A U-Th-Ta Isotope Study from Lanzarote in the Canary Islands. Geochim Cosmochim Acta, 63, 4081-4099. https://doi.org/10.1016/S0016-7037(99)00310-5

[32] Jagoutz, E., Palme, H., Baddenhausen, H., Blum, K., Cendales, M., et al. (1979) The Abundances of Major, Minor and Trace Elements in the Earth's Mantle as Derived from Primitive Ultramafic Nodules. In: Proceedings of the 10 th Lunar and Planetary Science Conference, Pergamon Press, Houston, 2031-2050.

[33] Krienitz, M., Haase, K., Mezger, K., Eckardt, V. and Shaikh-Mashail, M.A. (2006) Magma Genesis and Crustal Contamination of Continental Interpolate Lava in Northwestern Syria. Contributions to Mineralogy and Petrology, 151, 698-716. https://doi.org/10.1007/s00410-006-0088-1

[34] Sharkov, E.V. and Laz'ko, E. (1988) Igneous Rocks. AN. USSR. Nauka, Moscow, 310 p. (In Russian)

[35] Weinstein, Y., Navon, O., Altherr, R. and Stein, M. (2006) The Role of Lithospheric Mantle Heterogeneity in the Generation of Plio-Pleistocene Alkali Basaltic Suites from NW Harrat Ash Shaam. Journal of Petrology, 47, 1017-1050. https://doi.org/10.1093/petrology/egl003

[36] Ma, G., Wang, K.L., Malpas, J., Iizuka, Y., Xenophontos, C., et al. (2015) Melt Pockets and Spongy Clinopyroxenes in Mantle Xenoliths from the Plio-Quaternary Al Ghab Volcanic Field, NW Syria: Implications for the Metasomatic Evolution of the Lithosphere. In: Khan, A. and Deschamps, F., Eds., The Earth's Heterogeneous Mantle. A Geophysical, Geodynamical, and Geochemical Perspective, Springer, Berlin, 205257. https://doi.org/10.1007/978-3-319-15627-9 7

[37] Gasperini, D., Bosch, D., Braga, R., Bondi, M., Macera, P., et al. (2006) Ultramafic Xenoliths from the Veneto Volcanic Province (Italy): Petrological and Geochemical Evidence for Multiple Metasomatism of the SE Alps Mantle Lithosphere. Geochemical Journal, 40, 377-404. https://doi.org/10.2343/geochemj.40.377

[38] Stein, M. and Katz, A. (1989) The Composition of the Subcontinental Lithosphere beneath Israel: Inferences from Peridotite Xenoliths. Journal of Earth Sciences, 38, 7587. 